\title{
Fallopian Tube Torsion Due to Morgagni Cyst in Second Trimester Pregnancy: A Case Report
}

\section{Gebeliğin Ikinci Trimesterinde Morgagni Kistine Bağlı Fallop Tüpünde Torsiyon: Olgu Sunumu}

Fedi Ercan ${ }^{1}$,

Melike Bayman',

Osman Balci ${ }^{1}$,

Mehmet Aykut Yildirim²,

Teyfik Kucukkartallar ${ }^{2}$

${ }^{1}$ Department of Gynecology and Obstetrics, Meram Faculty of Medicine, Necmettin

Erbakan University, Konya

${ }^{2}$ Department of General Surgery, Meram

Faculty of Medicine, Necmettin Erbakan

University, Konya

Geliş Tarihi/Received: 16 March 2018

Kabul Tarihi/Accepted: 13 July 2018

Address correspondence to: Fedi Ercan, Department of Gynecology and Obstetrics,

Unit of Perinatology, Meram Faculty of

Medicine, Necmettin Erbakan University,

Konya, Turkey

e-mail: fediercan@gmail.com

ORCID

Fedi Ercan

https://orcid.org/0000-0003-2175-5405
Öz

Tubal torsiyon, özellikle gebelikte çok nadir bir durumdur. Burada gebeliği 24 haftasında akut karın kliniği ile kliniğimize başvuran bir olguyu sunmaktayız. Radyolojik ve biyokimyasal araştırmalar karın ağrısının nedenini açıklamadı ve laparatomi uygulandı. Ameliyat sırasında, daha önce ultrasonografik muayene ile görülen Morgagni kisti nedeniyle sağ fallopian tüpün torsiyone olduğu görüldü. Sırasıyla Morgagni kistine kistektomi ve fallopin tüpe de detorsiyon uygulandı.

Anahtar Kelimeler: Akut batın, fallopian tüp torsiyonu, Morgagni kisti, gebelik.

\section{Abstract}

Tubal torsion is a very rare case, especially in pregnancy. We present a case of a patient of 24 weeks gestation that was admitted to our clinic with acute abdomen. Radiological and biochemical investigations did not reveal the cause of abdominal pain which resulted in laparatomic exploration. During the operation, the Morgagni cyst, previously explored by ultrasonographic examination, and the right fallopian tube were found twisted among themselves. Cystectomy and detorsion was performed of the Morgagni cyst and the fallopian tube, respectively.

Keywords: Acute abdomen, fallopian tube torsion, Morgagni cyst, pregnancy.

\section{INTRODUCTION}

Morgagni cyst is among the most common benign, noninflammatory conditions of the fallopian tubes. These Wolffian duct remnants are simple cysts that occur near the fimbriated ends of the fallopian tube (1). Isolated torsion of a fallopian tube with Morgagni cyst is a rare occasion. The incidence of this clinical condition is one in $0.015 \%$ women (2). Isolated tuba torsion in pregnancy is much less common. Twelve percent of all isolated tubal torsion cases develop in the pregnancy (3). This condition is often confused with acute appendicitis or overt torsion. The right tubule is affected more frequently (3). We report a case of torsion right fallopian tube with Morgagni cyst during pregnancy.

\section{CASE}

At the age of 34 , gravida 2, para 1, pregnant woman presented with complaints of right lower abdominal pain at 24th week. Nausea and vomiting were also accompanied by inguinal pain. The patient had not undergone surgery before and there was no trait in his past medical history. There was no trait in the past obstetric history. There was no fever in the examination $\left(37.1^{\circ} \mathrm{C}\right)$ and arterial blood pressure was normal (130/85). The size of the pregnancy was compatible with the gestational age. Abdominal examination showed tenderness in the right lower abdomen. Hematocrit $30 \%$, white cell count 18,500 $/ \mathrm{mm}^{3}, 81.4 \%$ neutrophil, platelet count and urine analysis were normal. Diagnostic laparotomy was performed because of acute abdominal pain and

Cite this article as: Ercan $\mathrm{F}$, Bayram M, Balci O, Yildirim MA, Kucukkartallar T. Fallopian Tube Torsion Due to Morgagni Cyst in Second Trimester of Pregnancy: A Case Report. Selcuk Med J 2019;35(2): 130-132 


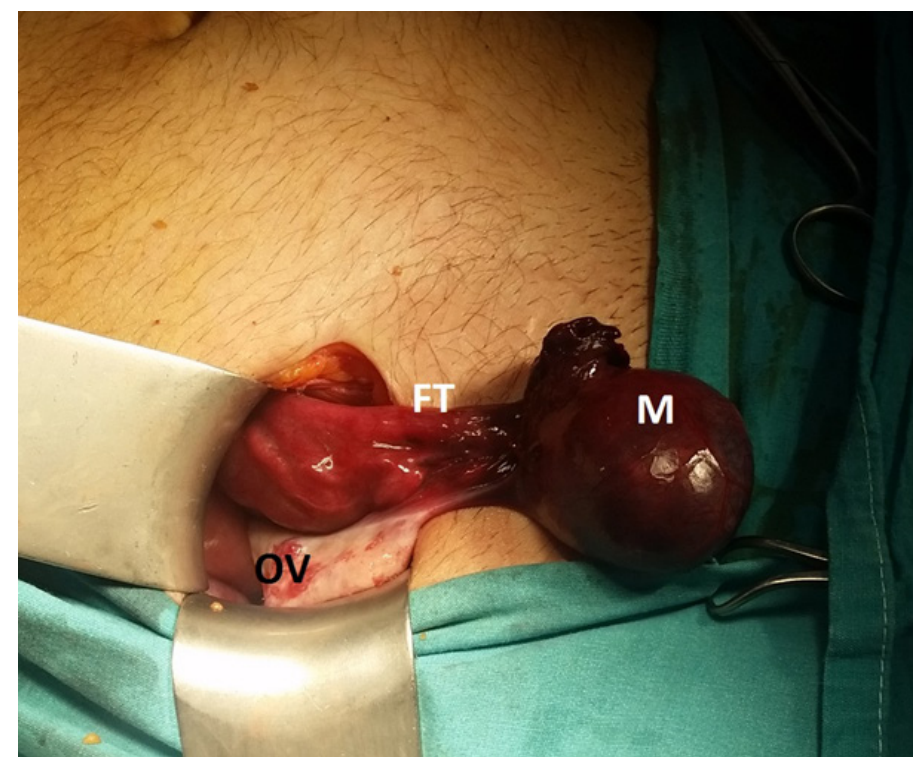

Figure 1. Intra-operative picture showing the Morgagni cyst at their expected location near the fimbriated ends of the right fallopian tube (FT) with purple color change due to deterioration of circulation. The normal right ovary (OV) and Morgagni cyst (M) can be seen.

findings of peritoneal irritation. A gangrenous, $3 \times 3$ $\mathrm{cm}$ paratubal Morgagni cyst was found during the exploration (Figure 1). The Morgagni cyst and the right tuba uterina were twisted around the itself. Left tube uterine, both ovaries and appendix were normal. The right fallopian tube was preserved and excision of the Morgagni cyst was performed. Histopathologic examination showed severe congestion and hemorrhage in the wall of the Morgagni cyst. The next day after surgery, sublingual tocolysis was needed. He was discharged on the fourth postoperative day.

The rest of your pregnancy passed smoothly. The patient gave birth at 38th week with cesarean on his own request. The pregnant woman gave birth to a healthy baby boy, 3451 grams. No fetal or maternal complications occurred during and after delivery.

\section{DISCUSSION}

Surgical interventions not of obstetric causes are performed in $0.2-2.2 \%$ of all pregnancies, being appendicitis the most common one (4). Adnexal torsion is rare and is one of the gynaecological causes of acute lower abdominal pain occurring in one every 5000 pregnancies (1). It can occur in all trimesters, being more frequent in the first one, between the 6th and 14th weeks. The cause of this pregnant tuba torsion seems to be Morgagni cyst and pregnancy (5). The most common symptoms are inguinal pain and pain spreading to the thigh. Other related symptoms nausea and vomiting $(2,6)$. Body temperature, white blood cell count and erythrocyte sedimentation rate may be normal or slightly elevated (2). The present case was presented with right lower abdominal pain, nausea and vomiting. White blood cell counts were high in laboratory tests. Sedimentation was not looked at. These diagnosis are not clear before operation because they are seen in other common diseases. The differential diagnosis for second trimester pregnancies includes acute appendicitis, twisted ovarian cyst, degenerative leiomyoma, and abruptio placenta. In this present case, preoperative diagnosis was acute appendicitis (4).

Morgagni cysts are Wolffian duct remnants filled with simple serous fluid are located at the fimbriated ends of the fallopian tubes. These are primarily asymptomatic. Most of the Morgagni cyst achieve the size of $1 \mathrm{~cm}$ or so and rarely undergo torsion with fallopian tube (7). After torsion they may become symptomatic and be a cause of intermittent or acute abdominal pain. Fortunately, they can be removed with preservation of the fallopian tube. Most Morgagni cysts were incidentally discovered in cases of various pelvic surgeries. The direct diagnosis of Morgagni cysts is difficult, but sonographical careful search of pelvic disease was helpful in making earlier diagnosis and better characterization of twisted adnexial cysts (8). As a result although torsion of Morgagni cyst with fallopian tube during pregnancy is uncommon, it should be included in the differential diagnosis of acute abdomen in pregnancy. Early delivery of the operation decision will reduce obstetric complications. It will also provide protection of the tuba uterina.

Conflict of interest: Authors declare that there is no conflict of interest between the authors of the article.

Financial conflict of interest: Authors declare that they did not receive any financial support in this study.

Address correspondence to: Fedi Ercan, Department of Gynecology and Obstetrics, Unit of Perinatology, Meram Faculty of Medicine, Necmettin Erbakan University, Konya, Turkey e-mail: fediercan@gmail.com GSM: 5058955309

\section{REFERENCES}

1. Mancuso A, Broccio G, Angio LG, et al. Adnexal torsion in pregnancy. Acta Obstet Gynecol Scand 1997;76(1):83-4.

2. Phupong V, Intharasakda $P$. Twisted fallopian tube in pregnancy: A case report. BMC Pregnancy Childbirth 
2001;1(1):5.

3. Boyar Hİ. Preoperatif tanı alan izole fallop tüpü torsiyonu. Selçuk Tıp Derg 2014;30(2):84-5.

4. Upadhyay A, Stanten S, Kazantsev G, et al. Laparoscopic management of a nonobstetric emergency in the third trimester of pregnancy. Surg Endosc 2007;21(8):1344-8.

5. Kahramanoglu I, Eroglu V, Turan H, et al. Isolated adnexal torsion in a 20-week spontaneous twin pregnancy. Int J Surg Case Rep 2016;23:138-40.

6. Ergenoglu M, Yeniel O, Peker N, et al. Tubal torsion during pregnancy-case report. Gynecol Pol 2011;82(4):287-90.
7. Erdemoğlu M, Kuyumcuoğlu U, Kale A. Pregnancy and adnexal torsion: Analysis of 20 cases. Clin Exp Obstet Gynecol 2010;37(3):224-5.

8. Bohîlțea RE, Cîrstoiu MM, Turcan N, et al. Ultrasound diagnostic of mesonephric paraovarian cyst - case report. J Med Life 2016;9(3):280-3. 